\title{
Multivariate Statistical Process Control
}

\section{Kulahci, Murat}

Published in:

Workshop on Farm Animal and Food Quality Imaging 2013

Publication date:

2013

Document Version

Publisher's PDF, also known as Version of record

Link back to DTU Orbit

Citation (APA):

Kulahci, M. (2013). Multivariate Statistical Process Control. In Workshop on Farm Animal and Food Quality Imaging 2013: Espoo, Finland, June 17, 2013, Proceedings (pp. 29). Technical University of Denmark. DTU Compute Technical Report-2013 No. 12

\section{General rights}

Copyright and moral rights for the publications made accessible in the public portal are retained by the authors and/or other copyright owners and it is a condition of accessing publications that users recognise and abide by the legal requirements associated with these rights.

- Users may download and print one copy of any publication from the public portal for the purpose of private study or research.

- You may not further distribute the material or use it for any profit-making activity or commercial gain

- You may freely distribute the URL identifying the publication in the public portal

If you believe that this document breaches copyright please contact us providing details, and we will remove access to the work immediately and investigate your claim. 
Multivariate Statistical Process Control

\author{
Murat Kulahci \\ Technical University of Denmark, Applied Mathematics and Computer Science
}

\begin{abstract}
As sensor and computer technology continues to improve, it becomes a normal occurrence that we confront with high dimensional data sets. As in many areas of industrial statistics, this brings forth various challenges in statistical process control (SPC) and monitoring for which the aim is to identify "out-of-control" state of a process using control charts in order to reduce the excessive variation caused by so-called assignable causes. In practice, the most common method of monitoring multivariate data is through a statistic akin to the Hotelling's $T^{2}$. For high dimensional data with excessive amount of cross correlation, practitioners are often recommended to use latent structures methods such as Principal Component Analysis to summarize the data in only a few linear combinations of the original variables that capture most of the variation in the data. Applications of these control charts in conjunction with image data are plagued with various challenges beyond the usual ones encountered in current applications. In this presentation we will introduce the basic ideas of SPC and the multivariate control charts commonly used in industry. We will further discuss the challenges the practitioners are facing with in the implementation of these charts.
\end{abstract}

